\title{
Patterns of Relationships in Polygamous Families in Malaysia
}

\author{
Muhammad Ajib Abd Razak, Intan Hashimah Mohd Hashim, \& Syazwani \\ Drani
}

To Link this Article: http://dx.doi.org/10.6007/IJARBSS/v11-i3/8913

DOI:10.6007/IJARBSS/v11-i3/8913

Received: 07 January 2021, Revised: 01 February 2021, Accepted: 20 February 2021

Published Online: 08 March 2021

In-Text Citation: (Razak et al., 2021)

To Cite this Article: Razak, M. A. A., Hashim, I. H. M., \& Drani, S. (2021). Patterns of Relationships in Polygamous Families in Malaysia. International Journal of Academic Research in Business and Social Sciences, 11(3), 7-18.

\section{Copyright: @ 2021 The Author(s)}

Published by Human Resource Management Academic Research Society (www.hrmars.com)

This article is published under the Creative Commons Attribution (CC BY 4.0) license. Anyone may reproduce, distribute, translate and create derivative works of this article (for both commercial and non-commercial purposes), subject to full attribution to the original publication and authors. The full terms of this license may be seen at: http://creativecommons.org/licences/by/4.0/legalcode

Vol. 11, No. 3, 2021, Pg. 7 - 18

Full Terms \& Conditions of access and use can be found at http://hrmars.com/index.php/pages/detail/publication-ethics 


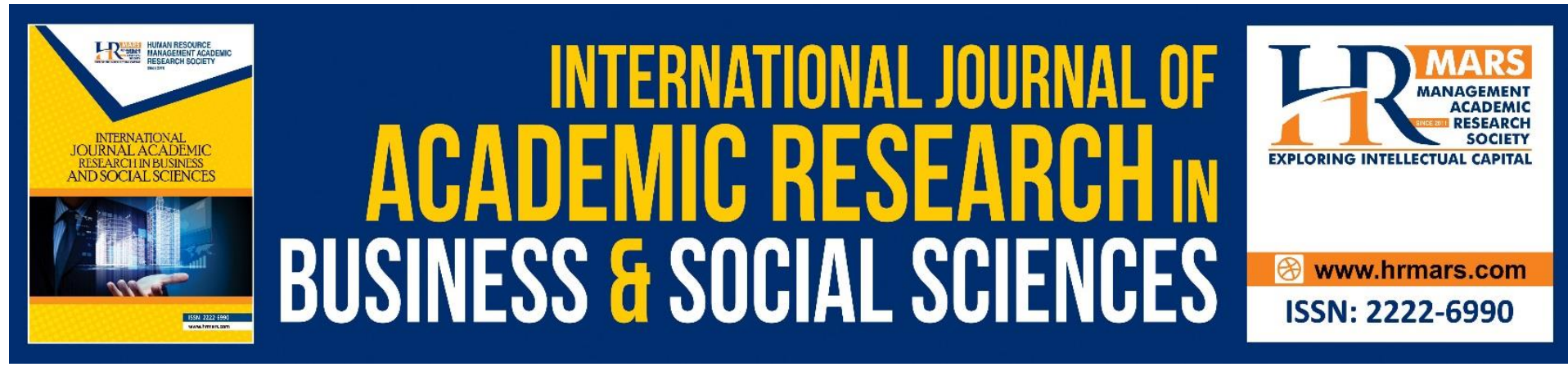

\title{
Patterns of Relationships in Polygamous Families in Malaysia
}

\author{
Muhammad Ajib Abd Razak¹, Intan Hashimah Mohd Hashim², \\ \& Syazwani Drani ${ }^{2}$ \\ ${ }^{1}$ Program of Psychology, Faculty of Social Sciences \& Humanities, Universiti Kebangsaan \\ Malaysia, 43000 UKM Bangi, Selangor, Malaysia, ${ }^{2}$ School of Social Sciences, Universiti Sains \\ Malaysia, Pulau Pinang,11800 \\ Email:muhdajib@ukm.edu.my, hashimah@usm.my, syazwanid@usm.my
}

\begin{abstract}
The purpose of this study was to identify patterns of relationships in polygamous families in Malaysia. A total of six families were interviewed. This involved 21 respondents consisting of six husbands, five first wives, five second wives, one third and fourth wife, as well as three children. In-depth, face-to-face interviews were conducted based on the interview questions. Interviews were transcribed and analyzed using thematic analysis and six themes emerged as follows: relationships of warmth and rejuvenation; use of multi-way communication and a veto; valuing straightforward and deep conversations; feeling well treated as long as comparisons can be avoided; maintaining close relationships; and fair and friendly treatment. The findings of this study are expected to help mitigate the perception that polygamous families always produce bad family environments and are dysfunctional. Instead it is shown that polygamous families often produce more positive, better relationships than those in monogamous marriages. The findings of the study are explained, and major implications discussed, in detail.
\end{abstract}

Keywords: Relationships, Polygamy, Family, Patterns

\section{Introduction}

Polygamy is a well-known form of marriage yet remains a controversial practice even though it is common in the Middle East, Africa, Europe and other countries that practice sharia law. An estimated $20 \%$ to $50 \%$ of polygamous marriages are recorded among low-educated husbands and wives of Muslims and rural residents (Slonim-Nevo \& Al-Krenawi, 2006). Hayase \& Liaw (1997) predict that polygamy will increase each year as more and more well-educated, successful husbands also marry more than one woman. In the US, for example, more than 80,000 people practice polygamy in western Utah, where polygamy is legalized and the practice is increasing each year (Llewellyn, 2006). This is different in Canada where such practices are not allowed at all and it is an offense to be polygamous. Zeitzen (2018) sees polygamy as a practice of resistance based on the sentiments of many polygamy practitioners. Polygamy is also a challenge because of the fundamental issue of doubts as to a husband's ability to be fair when married to more than one woman at one time. Nuraimirah, Norulhuda 
and Nur Saadah (2019) revealed that, changes from core family structure have led to changes in psychological, change in behavior and lack of financial resources. For example, Muslimmajority countries such as Tunisia and Turkey have forbidden polygamy because it has been found that women in polygamous marriages are treated unfairly in many respects by their husbands (Al-Krenawi, 2014). Questions are also emerging as to whether women who choose to live in polygamous marriages are doing so voluntary or are religiously motivated, as opposed to being genuinely in favor of polygamy (Strauss, 2012).

In analyzing the changing relationships between husbands and wives over the course of a polygamous marriage. The entrance of the second wife into the marriage can manifest itself in three ways, namely, (1), the first wife resigns (requests a divorce), (2), she becomes more hostile and competitive, (3) she agrees to cooperate. Wheeler (1999) also argues that relationships between husbands and wives indirectly create ongoing competition and cause them to feel pressured and anxious as they strive to maintain their dignity and self-esteem, and due to the responsibility, they feel to become more virtuous and a better spouse.

Previous studies reveal that for those husbands who have a better relationship with their junior wives than their senior wives, this is due to the first wife feeling she has failed as a wife and being disappointed in not being able to fully fulfil her own wishes (Al-Krenawi, 1999). Thobejane (2016); Mukhuba (2017) have found that some women in polygamous marriages describe their husband as a being dominant, controlling over decision making and entrenching a patriarchal system. Study on gender differences suggests that the lower status and power possessed by women in society are mirrored in the marital relationship (Rozmi, Azlan \& Yusoff, 2015). However, husbands who are able to provide intimacy and trust, and treat their wives justly can contribute to good cooperation and relations between these wives (Seeley, 2012). Nonetheless, in a patriarchal family system, husbands tend to be more dominant and in control of the family hierarchy. In polygamous marriages, husbands tend to provide less space for wives to discuss matters and may not overly care about their emotions and feelings. This is because the husband feels that he needs to be fully respected and cannot tolerate his decisions being rejected (Mukhuba, 2017). To understand polygamy, it is important to know that most polygamous families implement a patriarchal system (Jankowiak, 2008). Other studies showed that there was a difference in parenting skills between men and women and psychological well-being among parents are one of the very important aspects to ensure the well-being of a family (Asmawati et al., 2015).

On the other hand, culture has also been found to be an important factor in influencing the way people view love (Hoesni et al., 2013). The husband has a lot of power and control and is able to veto his wives in the name of religion and traditional values. This has led to research finding that the practice of polygamy can result in competition, unequal distribution of household resources, co-wife envy and failure to do justice to all the family members (SlonimNevo \& Al-Krenawi, 2006; Yilmaz \& Tamam, 2018; Abdullah, Abdullah, \& Ferdousi, 2015). Given this, many polygamous wives are reported to have higher depression scores than monogamous wives (Ozer, Orhan \& Ekerbicer, 2013). Researchers have found that family members in polygamous households have negative experiences that lead to mental health problems because of the failure of the husband to maintain harmony. While families often do experience mental health problems, in particular women (most commonly the senior wife) and children (Muhammad Ajib, Intan Hashimah \& Syazwani, 2020), researchers and family practitioners have rarely paid attention to exploring patterns of relationships within polygamous families, especially in the Malaysian context. In this light, this research has been 
conducted to explore possible factors that can contribute to more positive family functioning by understanding the patterns of relationships that are experienced by family members.

\section{Objective}

To examine patterns of relationships in polygamous families in Malaysia. In this study, relationships are explored with regard to communication, support, conflict resolution, intimacy, face-to-face frequency, and commitment among family members in the context of a polygamous life. The relationship experiences of husbands, wives and co-wives, and children were explored. The exploration of different forms of relationships extended to the nature of the relationships of each family member.

\section{Method}

This study uses a qualitative research method, consisting of in-depth interviews of six families who practice polygamy. Objective sampling and snowballing techniques were used to identify and select respondents who met the inclusion criteria. Six families were interviewed, and there were 21 total respondents consisting of six husbands, five first wives, five second wives, one third and fourth wife, and three children. All of these families have been friends for between two to 10 years. All respondents agreed and gave written consent to participate in this study. All interview sessions were recorded into an audio recorder and then transcribed for data encoding purposes. Each interview session was conducted at the respondent's home at an appointment time specified by the respondent. Respondents were given the freedom to choose their place and time of interview, with due consideration to the factors of time, comfort, confidentiality and suitability of the respondents. The process of data collection took 8 months from April 2019 to November 2019. Recruitment of respondents was very challenging as not all family members were willing to cooperate and volunteer in this study by sharing personal information about their family with the researcher. The data encoding process consisted of three phases, as suggested by Brown and Clarke, to identify themes that arise from the experiences of polygamous families. Table 1.0 below summarizes the demographic profile of the respondents in the study. 
Table 1.0 Demographic Profile of Respondents

\begin{tabular}{llcll}
\hline Family & \multicolumn{1}{c}{ Respondent } & Age & $\begin{array}{c}\text { Years of } \\
\text { Polygamy }\end{array}$ & Occupation \\
\hline (A) & Husband & 51 & 10 & Businessman \\
& First wife & 51 & 10 & Teacher \\
& Second wife & 36 & 10 & Teacher \\
& Son of the $1^{\text {st }}$ wife & 26 & 10 & Accountant \\
(B) $\quad$ Husband & 37 & 4 & Businessman \\
& First wife & 37 & 4 & Teacher \\
& Second wife & 36 & 4 & Teacher \\
& Third wife & 42 & 4 & Business \\
& Fourth wife & 31 & 3 & Housewife \\
& Son of the $1^{\text {st }}$ wife & 14 & 4 & Student \\
(C) Husband & 52 & 10 & Businessman \\
& First wife & 48 & 10 & Housewife \\
& Second wife & 39 & 10 & Housewife \\
& Son of the $1^{\text {st }}$ wife & 22 & 10 & Businessman \\
(D) Husband & 37 & 2 & Officer \\
& First wife & 36 & 2 & Housewife \\
Second wife & 22 & 2 & Student \\
(E) Husband & 50 & 17 & Lecturer \\
& First wife & 17 & Housewife \\
(F) Husband & 34 & 7 & Businessman \\
& Second wife & 34 & 7 & Teacher \\
& & & \\
\hline
\end{tabular}

\section{Results}

\section{Perspectives of the Husbands}

\section{i. Relationships of warmth and rejuvenation}

A few polygamous husbands claim that their relationships tend more towards warmth and rejuvenation, becoming good and harmonious over time - different to the relationship at the beginning of their first marriage. Below are some sample responses from the respondents in this study;

"...How is the relationship? mmm...for me it is more friendly now...yes...now I feel that the relationship is flowering...it is like a monogamous relationship and, at my age right now, it is quite monotonous. Yet it also relaxing, and we feel more rejuvenated...' (husband from family A).

'...Thankfully...the relationships get better over time, and they give me undivided love and will continue to do so. Be sure to be proper in your marriage and be responsible and never play around. So, if you do it right, nobody should be too worried. Everyone can mess around with the situation, but with the passage of time it is all good. However, it can be a bit daunting for the second and third wives, for two or three people to be married at the same, especially in terms of dealing with each other..." (husband from family B).

"...Thanks to God...my relationship with my first wife is always good ... everything is fine and safe ... my first and second wife have a good acceptance of living together. The relationships are much better than at the beginning of my new marriage when there were a lot of disagreements. I used to get all kinds of attacks at the time I decided to marry my second 
wife...there was something wrong and conflicts were happening ... there were lots of emotions at that time...if I weren't strong enough to hold on in this relationship, I think I might be monogamous right now (husband from family $\mathrm{C}$ ).

Generally, polygamous family relationships are better if the husband treats his wife, cowife/wives and son well. The husbands from families $A, B$ and $C$ are satisfied with their decision to live a polygamous lifestyle, even though they have faced a lot of resistance from certain people. At the start of the polygamous marriage, the marriage did not function well because the first wife was not ready to accept polygamy. Consequently, the relationship between the first and second wife was distant. But the flaws in the marriage begin to iron themselves out and things start to run more smoothly compared to the situation at the beginning of the polygamous marriage. According to Slonim-Nevo \& Al-Krenawi (2006), polygamy is a complicated structure for family members, particularly for the husband and wives. However, there are many ways and techniques that can be implemented by the husband to enable the family to function well. Overall, the experience of practicing polygamy is significantly more positive than the perceived attitudes about polygamy (Al-Krenawi, Graham \& Jacobsen, 2006). This study clearly shows that most husbands feel much better in a polygamous family if they focus on caring for the emotions and feelings of family members, rather than thinking about the negative elements that occur in the family.

\section{ii. Use of multi-way communication and a veto}

Some of the husbands stated that in a polygamous relationship, there is a need for using multi-way communication and a veto from time to time on the wives and sons. According to the husbands of the $A$ and $B$ families, multi-way communication is necessary to ensure messages are well delivered to all family members. Multi-way communication sometimes needs to be one-way or two-way, depending on the issue or situation in question. If it seems difficult to reach an agreement, then the husband may use a veto once in a while. The responses from the husbands of families $B$ and $A$ are quoted below;

"... I use multi-way communication...sometimes we need to use one or two-way communication...it depends on the situation...for example, if using one-way communication and it turns out that it is difficult to reach agreement, then the husband should use a veto to ensure the communication achieves agreement... (husband from family B).

"...the kind of communication depends on the nature of the husband. The husband needs to control it...control is an important element for husbands who have more than one wife...controlling communication is the best method to make all the wives follow my instructions and orders. This is in line with Quranic verse 228 in surah Al-Baqarah..." (husband from family $A$ ).

According to Mukhuba (2017) and Jankowiwk (2008), most polygamous families implement a patriarchal system. The husband has the absolute power to make sure the family members obey him. A veto is used to facilitate family communication and facilitate decision-making, so as to sustain harmony in the family.

\section{B. Perspectives of the Wives \& Co-Wives \\ i) Valuing straightforward and deep conversations}

The findings showed that most of the wives and co-wives value straightforward and deep conversations with their husbands in their daily relationship. According to the first wife from family $A$, and the second wives from families $C$ and $F$, straightforward communication is the best method to make it easier for themselves to understand each other, avoid problems and 
keep themselves in a comfortable zone. They want a happy life without any conflict. Engaging in open, direct communication is the best way to achieve happiness in a polygamous family. Below are a few interview quotes from some of the respondents on this matter:

"..We truly value trust in this family... We like to be honest about everything... such as when we are heartbroken or dissatisfied...at the beginning there was a negative outlook but we didn't keep this... we talked directly...this is our secret that we maintain until now and it's why we remain in this polygamous situation... (first wife from family A)

"My husband and I don't talk too much... it's just silence, even from my husband...sometimes we talk about what many of us talk about ... or we talk about important issues ...sometimes we get angry with each other... If I dislike what is happening, sometimes I nag. but my husband and I are so open...but my husband and the other wives seem to have nothing to hide ... nothing to talk about ... nothing to keep secret...but you'll die if you hide and keep feeling guilty... (second wife from family C).

"It's like this... my husband and I communicate openly...very openly... we don't just keep silent and bury ourselves.... we live in the same house but we don't want to become lame and not talk and chat to other people... when we are aware that something bad has happened, we don't let it linger...our communication is open... (second wife from family F)

In polygamous marriages, wives present significant psychological problems such as trauma, depression and dilemma, as a result of conflicts with husbands, declines in happiness, and changes in family dynamics (Al-Krenawi \& Graham, 2006). However, this study found that the wives practice open communication to alleviate the pain associated with dissatisfaction, negative thoughts, restless hearts and spousal suspicion.

\section{ii) Feeling well treated as long as comparisons can be avoided}

According to the second wife from family $C$ and third wife from family $B$, the treatment they receive from their husband is good even though it is far from that typical of a monogamous marriage. The findings of this study indicate that the wives feel well treated as long as they don't need to compare their treatment to that of their co-wife/wives. This means that as long as the wife is not aware of what their husband is giving to the other spouse, such as wedding gifts, vacations, buying necessities and so on, then they still think their husband is treating them fairly and well. Below are some interview quotes from the two abovementioned respondents on this matter:

"...He is honest in this polygamy, but he can't be too honest. He is not $100 \%$ honest ... For example, my husband told me he loves me more than the other wife... I realize I should not believe that expression of love. We can't be honest about everything... including asking what the husband is doing with the other wife...I did this with my co-wives and I feel you can't be too honest...if you are too honest and compare things, it will cause conflict and be heart wrenching... (Third wife from family B).

"...My husband sometimes returns from the first wife's house and brings me some leftover dishes...but no one wants to know what a husband does with his first wife. This will just cause fights and bad thoughts about each other, and it won't have any benefits. The family needs to remain the same... (Second wife from family $\mathrm{C}$ ).

The findings show that from the wives' perspective, they feel they are well treated as long as they don't need to compare themselves with, or know what's going on with, the other spouses. This allows them to control their emotions, remain positive, and avoid conflicts and fights. Jankowiak, Sudakov and Wilker (2005) report that relationships between wives often result in conflicts, ranging from endemic conflict, resentment and hostility, as well as 
pragmatic cooperation in the wake of events that lead to hostility - thus ultimately leading to harmonious relationships. However, Moran (1990) argues that conflicts between wives stem from their own goal of monopolizing their husbands to fulfill certain rights such as time and attention. This study found that the wives try to avoid attitudes that can damage good relations in order to maintain a positive home environment.

\section{Perspectives of the Sons \\ i) Maintaining close relationships}

From a child's perspective, family relationships change in a polygamous situation. Children state that their relationship with their father diminishes in the early stages of a polygamous relationship, and then the nature of the relationships with the father, mother and stepmother varies. The children from families $B$ and $C$ say that they are closer to their biological mother than their father and stepmother. Nonetheless, the latter are also always supportive and caring. Below are quotes from some of the respondents on this matter:

"...actually, my relationship with my dad is okay, but in reality, I haven't felt that happy with my dad since I was in secondary school. We are not so close because he doesn't see me that often. Like at school ceremonies, it is just my mother who comes and celebrates with me, but my dad is absent. However, my dad does show he cares about me by supporting me, especially when I have an exam at school. Sometimes, my dad tells me to accept my stepmother and other siblings and treat them well. My dad is also concerned about my necessities like school utilities, pocket money, and so on..." (son from family B)

"... Thanks to God, my relationship with my father is good. It was distant at the beginning of the polygamous situation, but now we are close and don't fight. Because I'm the only boy, whatever my dad orders me to do, I will do - same with my mom. My dad places a lot of hope on me because I'm the boy in the family...in the past, when my dad wanted to marry someone else, I felt a little bit upset. However, later on I was okay with my dad's decision when I saw my dad struggling to manage my school and academic matters..." (son from family C)

The findings of this study are in line with Khasawneh, Hijazi \& Salman (2011), where, based on the children's perspectives of polygamous families, children see father-to-child relationships as not discriminating between family members. Children have no choice but to adapt and see polygamy as an obligation for them to endure in their lives. Researchers have argued that family structure is very important to both child and adult development. and that polygamy also indirectly benefits a child's experiences (Al-Sharfi, Pfeffer \& Miller, 2016). Some studies, such as Al-Krenawi, Graham \& Slonim-Nevo, (2002); Elbedour, Onwuegbuzie \& Alatamin (2003) and Al-Shamsi \& Fulcher (2005), have found that polygamy has a negative impact on the relationship between children and fathers, and can cause psychological problems and mental health problems in children. However, unlike those studies, this study looked at fathers, wives and co-wives who maintain good relations in terms of income, communication, academic matters and career concerns, who are consistent in their support and understand their children's needs, and who help their children adapt to the changing dynamics of a polygamous family. Ng Ying and Wan Shahrazad (2017) found that, the strong emotional bonding among family members can serve as a significant social support for family members. When adolescents have adequate social support from their family, it will foster the process of resilience reintegration 


\section{ii) Fair and friendly treatment}

The sons from these polygamous families feel their fathers are consistent in treating them in a fair and friendly manner - as is the case with their biological mothers and stepmothers. Birth mothers continue to treat their children just as they did before polygamy, bringing them up to be dignified, confident and friendly, while fulfilling their needs as children. The sons from families A, B and C stated that, on average, their fathers are fair and good, always asking important things about their school and career needs, while stepmothers are also very concerned, offering help and carrying out activities. Below are quotes from some of the respondents on this matter;

"... I am treated the same as I was before polygamy. There is no difference from the past until now. My dad has never treated anyone better than anyone else, everything is fair. My dad still takes care of me and my sister well, especially because I'm the only boy from my mom. There is another five-year-old boy from my stepmother, but we are treated the same. My dad shows his love to all his sons and is able to fulfill this even though he is married to someone else and has other sides of the family..." (son from family $\mathrm{C}$ )

"...Everything is all right ... my dad doesn't show me that he loves me much. He is more likely to ask me what I want but doesn't ask enough about my personal matters. However, my dad does want to help me. When we meet, he kisses and hugs me. My dad has told me to study hard and respect my mother ... don't make any problems... and don't think too much about motherhood and the family situation ... just study..." (son from family B)

The finding here is that parents continue to be consistent in treating their children in a fair and friendly manner, despite being in a polygamous relationship. This finding is inconsistent with research by Chikwature \& Oyedele (2016); Elbedour, Bart, \& Hektner, (2000); Al-Krenawi \& Lightman, 2000), which concludes that children from polygamous families experience family problems such as domestic violence, marital conflict, divorce, abuse, neglect, lack of responsibility and poor academic performance. In contrast, the findings of this study demonstrate that children are still well treated despite some family conflicts as long as the issues concerned can be controlled by the family properly. The well-being of the children in the study is preserved even if these children expressed some dissatisfaction with their fathers for the way they manage their polygamous relationships.

\section{Conclusion}

Overall, this study presents six key themes in identifying forms of relationships in polygamous families from the perspectives of husbands, wives and children, namely, relationships of warmth and rejuvenation; use of multi-way communication and a veto; valuing straightforward and deep conversations; feeling well treated as long as comparisons can be avoided; maintaining close relationships; and fair and friendly treatment. These findings do not necessarily reflect polygamous life in poor working conditions, which was the focus of the studies of Al-Krenawi and Slonim-Nevo (2008); Al-Krenawi, Slonim-Nevo \& Graham (2006); Al-Krenawi (1999) found that polygamous relationships have a negative impact on the mental health of family members, cause social difficulties, lead to poorer family relationships, and negatively affect social functioning and psychological well-being. However, this study found that even though, from the husband's perspective, starting a life of polygamy is difficult because of opposition and disapproval of wives and children, a lack of experience in controlling the emotions and feelings of both spouses, financial problems, time management and managing family conflict at the beginning of the polygamous relationship - later on things improve and get more stable. From the perspective of wives, polygamous life is difficult in the 
context of communication because it involves their heart and feelings. As such, direct and transparent communication is always practiced, ensuring that there are no conflicts and disagreements between the husband and co-wives. Comparisons and questions about personal matters involving the husband and his other wives should be avoided. From the children's perspective, there is indeed some anger and dissatisfaction towards their fathers because of polygamy, because the children are very concerned about the feelings and emotions of their biological mother and fear that she will endure a loss of love and affection. However, in the context of relationships, the children still feel well treated by their father, mother and stepmother - and their father remains concerned about their welfare and needs. The results of this study should make the public, counselors, policy makers, scholars, nongovernmental organizations (NGOs), therapists, and other decision makers aware that not all polygamous families experience prolonged domestic violence, or other negative issues and conflicts. However, polygamous family members need support, guidance, and psychological help to ensure that they are psychologically stable, and their well-being looked after - just like in any monogamous family. These findings can also serve as a guide for therapists in providing counseling and consulting services to any individual who is in the process of starting a polygamous life, in order that they can gain a better understanding of the true nature of polygamy.

Ethical approval was granted by the Human Research Ethics Committee, University of Science, Malaysia (Ref USM/JEPem/18070324). Participants consented to anonymized quotes being used in dissemination.

\section{References}

Al-Krenawi, A., Slonim-Nevo, V., \& Graham, J. R. (2006). Polygyny and its impact on the psychosocial well-being of husbands. Journal of Comparative Family Studies, 37(2), 174-189.

Al-Krenawi, A. (1999). Women of polygamous marriages in primary health care centers. Contemporary Family Therapy, 21(3), 417-430.

Al-Krenawi, A., Graham, J. R., \& Jacobsen, S. B. S. (2006). Attitudes toward and reasons for polygamy differentiated by gender and age among Bedouin Arabs of the Negev. International Journal of Mental Health, 35(1), 46-61.

Al-Krenawi, A., \& Graham, J. (2006). A Comparison of Family Functioning, Life and Marital Satisfaction, and Mental Health of Women in Polygamous and Monogamous Marriages. International Journal of Social Psychiatry, 52(1), 5-17.

Al-Sharfi, M., Pfeffer, K., \& Miller, A. K. (2016). The effects of polygamy on children and adolescents: a systematic review. Journal of Family Studies, 22(3), 272-286.

Al-Krenawi, A., \& Slonim-Nevo, V. (2008). Psychosocial and familial functioning of children from polygynous and monogamous families. The Journal of social psychology, 148(6), 746-764.

Al-Sharfi, M., Pfeffer, K., \& Miller, A. K. (2016). The effects of polygamy on children and adolescents: a systematic review. Journal of Family Studies, 22(3), 272-286.

Al-Shamsi, M.S.A., \& Fulcher, L.C. (2005). The impact of polygamy on United Arab Emirates' first wives and their children. International Journal of Child and Family Welfare, 1, 4655.

Al-Krenawi, A., \& Lightman, E. S. (2000). Learning achievement, social adjustment, and family conflict among Bedouin-Arab children from polygamous and monogamous families. Social Psychology, 140 (3), 345-355. 
Al-Krenawi, A. (2014). Psychosocial Impact of Polygamy in the Middle East. United States of America: Springer New York.

Abdullah, Abdullah, \& Ferdousi. (2015). The Fragile Status of a Muslim Wife: The Legal History of Polygamy in Malaysia. Journal of Family History, 40(2), 135-152.

Asmawati, D., Fatimah, Y., Zainah, Nor Ba'yah, A. K., \& Norahim, M. S. (2015). Kemahiran Keibubapaan, Kefungsian Keluarga Dan Kesejahteraan Psikologi Dalam Kalangan Ibubapa. Jurnal Psikologi Malaysia, 29(2), 32-42.

Chikwature \& Oyedele. (2016); Polygamy and Academic Achievement-A Case of Johanne Marange Apostolic Sect. European Journal of Research in Social Sciences, 4(5),26-40.

Elbedour, S., Onwuegbuzie, A. J., Alatamin, M. (2003). Behavioral Problems and scholastic adjustment among Bedouin-Arab families children from polygamous and monogamous marital structures: Some developmental considerations. Genetic, Social, and General Psychology Monographs, 129(3), 213-237.

Elbedour, S., Bart, W. M., \& Hektner, J. M. (2000). Scholastic achievement and family marital structure: Bedouin Arab ado- lescents from monogamous and polygamous families in Israel. Journal of Social Psychology, 140, 503-515.

Hayase, Y., \& Liaw, K. L. (1997). Factors on polygamy in Sub-Saharan Africa: Findings based on the demographic and health surveys. The Developing Economies, 35, 293-327.

Hoesni, S. M., Subhi, N., Alavi, K., \& Wan Azreena, W. J. (2013). Exploring Love and Marital Satisfaction among Married Malay Males. Pertanika J. Soc. Sci. \& Hum. 21, 59-68.

Llewellyn, J. R. (2006). Polygamy's Rape of Rachael Strong. United States of America: Agreka LLC.

Jankowiak, W. (2008). Co-wives, husband, and the mormon polygynous family. Ethnology, $47(3), 163-180$.

Jankowiak, W., Sudakob, M., \& Wilreker, B. C. (2005). Co-wife conflict and co-operation. Ethnology, 44(1), 81-98.

Khasawneh, O. M., Hijazi, A. H. Y., \& Salman, N. H. (2011). Polygamy and its impact on the upbringing of children: A Jordanian perspective. Journal of Comparative Family Studies, 42(4), 563-578.

Moran, M. (1990). Civilized women: gender and prestige in southeastern Liberia. Ithaca: Cornell University Press.

Mhukuba, T. T. (2017). The representation of patriach perception in selected African literary works. Gender \& Behaviour, 8567-8576.

Nuraimirah, Z., Norulhuda, S. K., Nur Saadah, M. A. (2019). Effect of Divorce on Children: Social Workers' Perspective. Jurnal Psikologi Malaysia, 33(3), 67-78.

Ng Ying, Y., \& Wan Shahrazad, W. S. (2017). Resilience as Mediator in the Relationship between Family Functioning and Depression. Akademika, 87(1), 111-122.

Ozer, A., Orhan, F. O., \& Ekerbicer, H. C. (2013). Sociodemographic variables and depression in Turkish women from polygamous versus monogamous families. Health care for women international, 34(11), 1024-1034.

Rozmi, I., Azlan, H. A. N., \& Yusoff, F. (2015). Assessing the Relationship Between Quality of Life and Marital Satisfaction Among Malaysian Married Couples. e-Bangi Journal of Social Sciences and Humanities, 2, 065-071.

Slonim-Nevo, V., \& Al-Krenawi, A. (2006). Success and failure among polygamous families: The experience of wives, husbands, and children. Family Process, 45(3), 311-330.

Strauss, G. (2012). Is Polygamy Inherently Unequal? Ethics, 122(3), 516-544. 
Seeley, J. (2012). The changing relationships of co-wives over time in rural Southern Uganda. Journal of Development Studies, 48(1), 68-80.

Thobejane, T. D. (2014). An exploration of polygamous marriages: a worldview. Mediterranean Journal of Social Sciences, 5(27), 1058-1066.

Wheeler, L. A. (1999). Personal polygamy: voices of 19th and early 20th century mormon polygamy (Doctoral dissertation). Retrieved from ProQuest Dissertations \& Theses Global. (Accession No. 304545970).

Yılmaz, E., \&Tamam. L. (2018). The relationship between polygamy and psychiatric disorders in Turkish women. International Journal of Social Psychiatry, 64(8), 821-827.

Zietzen, M. K. (2018). Elite Malay Polygamy: Wives, Wealth and Woes in Malaysia. New York: Berghan Books. 